\title{
Acute renal failure associated with a labetalol overdose
}

\author{
A. Korzets, P. Danby, M.E. Edmunds, J. Feehally and J. Walls \\ Department of Nephrology, Leicester General Hospital, Leicester, LE5 4PW, UK.
}

\begin{abstract}
Summary: A case of acute renal failure in association with a deliberate labetalol overdose is described. The possible pathogenetic mechanisms behind the deterioration in renal function are discussed. Treatment of $\beta$-blockade overdose, with special emphasis on the place of glucagon in such poisoning, is reviewed.
\end{abstract}

\section{Introduction}

Overdosing with beta-adrenergic blocking agents may lead to severe haemodynamic compromise and even patient death. ${ }^{1,2}$ Prolonged and severe hypotension, often in previously hypertensive patients, is common. However acute renal failure following an overdose with pure beta-blockers has been reported only once in a setting of complicated rhabdomyolysis. ${ }^{3}$ In addition, a reduction in the severity of experimental acute renal failure by using beta-blockers has been described. ${ }^{4}$

Labetalol, a non-selective $\beta$-blocker and a selective $\alpha_{1}$-antagonist, has caused acute renal failure in at least one patient. ${ }^{5}$ We hereby describe a second such case and discuss the possible pathogenic mechanisms involved together with therapy of such a potentially dangerous overdose.

\section{Case report}

A 25 year old male, previously healthy, was admitted 3 hours after self-ingestion of 6 grams of labetalol (thirty $200 \mathrm{mg}$ tablets) and 7 pints of lager. The labetalol tablets had been prescribed for the patient's father for hypertension. On initial examination the patient was responsive but drowsy, with a blood pressure of $40-65 / 25 \mathrm{mmHg}$ and pulse rate 72 regular/min. Respiration was slightly irregular and neurological examination normal. Oxygenation was adequate, but acidosis and a serum creatinine of $128 \mu \mathrm{mol} / 1$ were noted. An electrocardiogram showed normal sinus rhythm. A toxicology screen excluded salicylate or paracetamol overdosage. Initial therapy included atropine, isoprenaline and dobutamine but hypotension proved resistant to this therapy. Oligoanuria developed within 3 hours of admission

Correspondence: A. Korzets M.B., B.S.

Accepted: 16 May 1989 (urine output: $4-5 \mathrm{cc} /$ hour). On the afternoon of the first day of admission ( 15 hours after ingestion) glucagon therapy was started, using an intravenous bolus of $10 \mathrm{mg}$, and thereafter maintained at an infusion rate of $4 \mathrm{mg} / \mathrm{h}$. Isoprenaline was continued. Within 6 hours blood pressure had risen to $120 / 60 \mathrm{mmHg}$. However oligo-anuria persisted; serum urea had risen to $13.7 \mathrm{mmol} / \mathrm{l}$ and serum creatinine had risen to $354 \mu \mathrm{mol} / \mathrm{l}$. Creatine phosphokinase levels were normal. By the second day the patient was fully conscious and normotensive and ionotropic therapy was gradually withdrawn. On the 3rd day of admission the patient was transferred to the renal unit with severe renal failure (serum urea: $32.6 \mathrm{mmol} / \mathrm{l}$, serum creatinine: $806 \mu \mathrm{mol} / \mathrm{l})$. An abdominal ultrasound revealed a right kidney $12.1 \mathrm{~cm}$ in length and a left kidney $12.7 \mathrm{~cm}$ in length. No hydronephrosis was seen. Haemodialysis was commenced using a doublelumen subclavian vein catheter. The patient remained dialysis-dependent for 16 days. A spontaneous diuresis was noted on the 15 th day post-overdose, and by the 30th day serum creatinine had reached a nadir of $85 \mu \mathrm{mol} / \mathrm{l}$. Recent onset hypertension is now adequately controlled with nifedipine $20 \mathrm{mg}$ twice daily.

\section{Discussion}

Labetalol has a dual action as both a selective $\alpha_{1}$-antagonist and a non-selective $\beta$-blocker. It is used in the treatment of all forms of hypertension. ${ }^{6}$ Adverse side effects are minimal, but can include postural hypotension, dizziness, fatigue and less commonly depression, impotence and fever. ${ }^{7-9}$ Overdosage with labetalol is rare but acute renal failure with such an overdose has occurred. ${ }^{5}$

In 1984, Weinstein reviewed poisoning with $\beta$-blocking agents. He found no reports of acute renal failure and this despite the profound and long-lasting hypotension that often accompanies 
$\beta$-blockage overdosage. ${ }^{2}$ With this severe hypotension, autoregulation in the kidney is arguably lost and further dilatation of the preglomerular afferent arteriole does not take place. ${ }^{10}$ In such a setting both renal plasma flow and glomerular filtration rate would be expected to fall. However, the massive $\beta$-blockade produces an uninterrupted stimulation to $\alpha$-adrenergic receptors. This results in a post-glomerular efferent arteriole vasoconstriction, an increase in intraglomerular pressures and a possible maintenance of glomerular filtration rate. On the other hand, labetalol overdosages will have much the same characteristics of $\beta$-blockade, but its selective $\alpha_{1}$ receptor antagonism will also lead to an efferent arteriole vasodilatation, a fall in intraglomerular pressure and a sharp reduction in renal function. Such a haemodynamic mechanism has been postulated for acute renal failure ${ }^{11}$ and can be regarded as analogous to the acute renal failure seen when angiotensin converting enzyme inhibitors are given to patients with renal artery stenosis. $^{12}$

There can be no doubt that labetalol was instrumental in causing an oliguric acute renal failure in this patient. The patient had been healthy prior to

\section{References}

1. Khan, A. \& Muscat-Baron, J.M. Fatal oxprenolol poisoning. Br Med J 1977, 1: 552.

2. Weinstein, R.S. Recognition and management of poisoning with beta-adrenergic blocking agents. Ann Emerg Med 1984, 13: $1123-1131$.

3. Schofield, P.M., Beath, S.V., Mant, T.G. \& Bhamra, R Recovery after severe oxprenolol overdose complicated by rhabdomyolysis. Hum Toxicol 1985, 4: 57-60.

4. Iaina, A., Solomon, S. \& Eliahov, H.E. Reduction in severity of acute renal failure in rats by beta-adrenergic blockage. Lancet 1975, ii: $157-158$.

5. Smit, A.J., Mulder, P.O.M., De Jong, P.E. \& Van der Hein, G.K. Acute renal failure after overdose of labetalol. Br Med J 1986, 293: 1142-1143.

6. Kanto, J.H. Current status of labetalol, the first alpha-and beta-blocking agent. Int J Clin Pharmacol Ther Toxicol 1985 23: $617-628$.

7. Stricker, B.H., Heijermans, H.S.F., Braat, H. \& Norg, J. Fever induced by labetalol. JAMA 1986, 256L: 619-620.

8. Burris, J.F., Goldstein, J., Zager, P.G., Sutton, J.M., Sirgo, M.A. \& Plachetka, J.R. Comparative tolerability of labetalol versus propranolol, atenolol, pindolol, metoprolol and nadolol. J Clin Hypertens 1986, 3: 285-293. the overdose with a serum creatinine of $128 \mu \mathrm{mol} / 1$ on admission and became rapidly oligo-anuric and dialysis-dependent over 16 days following labetalol poisoning. Furthermore, no adverse interaction between labetalol and alcohol has been reported. Acute tubular necrosis is the most probable histological diagnosis, but as a spontaneous diuresis and recovery of renal function occurred, renal biopsy was not performed.

Early, intensive efforts must be made to correct the hypotension associated with labetalol overdose. It may be that the drug of choice is glucagon and not only a combination of $\beta$-agonists and atropine. In 1984 glucagon was the only treatment that consistently produced an increase in both blood pressure and heart rate when used to combat $\beta$-blocker overdose. All cases treated with glucagon have had a favourable outcome. ${ }^{2}$ Glucagon has also helped reverse hypotension secondary to anaphylactoid shock in a patient treated previously with a $\beta$-blocker.$^{13}$ It is felt that glucagon has potent ionotropic and chronotropic actions, whose adrenergic effects are minimally antagonized by $\beta$ blockers.

9. Gomez, G. \& Phillips, L.A. Labetalol in hypertension: a multicentre study in general practice. Curr Med Res Opin 1980, 6: $677-684$.

10. Rose, B.D. Renal circulation and glomerular filtration rate. In: Rose, B.D. (ed) Clinical Physiology of Acid-Base and Electrolyte Disorders. McGraw-Hill, New York, 1984, pp. 53-81.

11. Oken, D.E. Hemodynamic basis for human acute renal failure (vasomotor nephropathy). Am J Med 1984, 76: $702-710$.

12. Hricik, D.E., Browning, P.J., Kapelman, R. et al. Captoprilinduced functional renal insufficiency in patients with bilateral renal-artery stenosis or renal-artery stenosis in a solitary kidney. N Engl J Med 1983, 308: 373-374.

13. Zaloga, G.P., Delacey, W., Holmbee, E. \& Chernow, B. Glucagon reversal of hypotension in a case of anaphylactoid shock. Ann Intern Med 1986, 105: 65-66. 